DOI: https://doi.org/10.47405/mjssh.v5i9.471

\begin{tabular}{|c|c|}
\hline 1. 1.54 & Malaysian Journal of Social Sciences and Humanities (MJSSH) \\
\hline $\begin{array}{c}\text { Malaysian Journal of } \\
\text { solal sciences and }\end{array}$ & Volume 5, Issue 9, September 2020 \\
\hline (MJ-SSH) & e-ISSN : 2504-8562 \\
\hline & $\begin{array}{l}\text { Journal home page: } \\
\text { www.msocialsciences.com }\end{array}$ \\
\hline
\end{tabular}

\title{
Modern Theories and Islamic Concept of Jihad Impacting Pakistan Security Dilemma
}

\author{
Muhammad Tariq Javed 1 \\ 1International Relations Department, University of Peshawar, Pakistan \\ Correspondence: Muhammad Tariq Javed (tariqjavedup@gmail.com)
}

\begin{abstract}
Pakistan National Security is directly related to a mix of Islamic precepts and the implications of contemporary real politics. Initially modern theories were a philosophical response to priesthood of the time hedging Christianity for their own predominance. With the advent of Islam the West applied the same antipathy to the faith of Islam and later it impacted Muslim states and Regions. The West however, circumvented religion as historical legacy representing Christianity. Pakistan being part of wider Muslim world is prone to historically prejudiced; direct and indirect threats based on Modern political theories. Modern theories are Euro-centric owing to their war prone regional history. Islamic Security concepts characterize trans-border implication. Modern political and security perspective are based on; personal experience of the people gone through wars and civil chaos whereas Islamic concept of just war is based on faith absolutes and Meta narratives ${ }^{1}$. Modern theories imply human nature as a pivot to craft response in anticipation of a predetermined threat to justify pre-emption. Modern theories have become the seed of modern state policies. Islam makes it obligatory to prepare and built power to first deter and retaliate only under tyranny, oppression and under the threat of expulsion and extermination. Pakistan military initiative are deemed inspired by Islamic concept of Jihad and have become cause of her Security Dilemma due to prejudiced Western view. Islam emphasis on mankind as one whole universal community called 'Ummah'. The modern theories divide the world on National identifies and globalizes only trade and transactions. National Interest in modern theories is pivotal to the state policies. This marked difference is sometime purposely confused as a strategy to dub even a legitimate resistance or movement as Terrorism depending on National Interest expediency. The major cause of conflict is embedded in Islamic and modern political connotations of a just war. These polemical perspectives explain Pakistan Security Dilemma as part of the Muslim world and a need for negotiated understanding for peace and stability and interfaith harmony.
\end{abstract}

Keywords: Pakistan's security dilemma, crusades, modern theories, Jihad, realism, liberalism

\section{Introduction}

This article aims at theoretical explanation of Modern vs Islamic theoretical and ideological constructs of in the making of Pakistan Security Dilemma. This study juxtaposes most impacting Modern theories metadata narrative and concept of just war and Islamic view of 'Jihad'. Pakistan's Security Dilemma in this study has been framed in the terms of multiple theoretical variables and not in response to a particular military action between two big powers that spirals the security threshold. 
Modern theories are based on personal and collective experience of the literates and thinkers. Pakistan Security Dilemma is not a classic paradigm of an escalation that emits out of the single factor of military threat like Cuban crisis in October 1962 during cold war times, in which USSR and US became on the verge of launching nuclear war fearing nuclear attack from each other. Intensification of threats to Pakistan has many dimensions to it. Its single conflict with India sounds less threatening than the foreign predominance 'awe', influence, intriguing, and manipulations due to her character as a strategic, ideological and Islamic state in the contemporary international relations' realm.

Pakistan's nationalist, ethnic, linguistic, provincial, and secessionist tendencies permeating its political folds. These factors are open to international power politick manipulations and make a recipe for her Security dilemma. Pakistan has given higher bids to international power players to assuage international opinion and favourable resolution on the issue of Jammu and Kashmir with India. Compensating weakness with alliances at the cost of becoming part a bigger and escalating confrontation as compared to primary regional issue of Kashmir. This circumvention has complicated Pakistan's security.

\section{Moralist and Modernist Schools}

A major division of security is based on morality and power based theories. The first charges itself with faith, values and normative inspirations and places interest second to divine like religion, faith and ideological and normative values. Theory of Realism defines the interest in terms of power. It is amoral in character if inevitable but not necessarily as an evil practice. Both, however, strive to make their responses to the perceived security threats as legitimate, in pursuits of their set goals and objectives grounded in respective theories, concepts and ideologies. The process to articulate a justification of response leads to the extended range of security and securitization. A third view empirically correlates security with the features of power and trade. Mansfield (1994) argues that, "The relationship between security and economics is empirical issue". It focuses on the relations between power, trade and war, within the ambit of security. It further argues that, "One reason why many major issues remain unresolved is that empirical studies of war and trade generally fail to include the effects of both economic and political factors".

Moral model is a process of securitization of beliefs, ethos, dogmas, perceived values and abstract traditions of a nation that is inspired by religion and orthodoxy. In moral base model, a divine or moral obligation motivates for a certain security response. In moral model, force is used as a last resort under the underlying ethos of a moral obligation. In the case of power and realist model it is just the apprehension projected into fear and addressed by use of power and other coercive instruments to realize a perceived national interest. The fear emits from ideological and theoretical precepts shaped up by historical, societal prejudices and greed and grab of the economic resources of other nations. These goals are realized through political modus operandi based on modern political theories by looking at contemporary issues through the ethos of historical ambiguities. Crusades and civilizational prejudices which matter in quiet a different context and construe the aims of modern international political objectives.

Moral school of thought believes that security is about safeguarding values and traditions nurtured with religious absolutes. Commonly, a security response is provoked when security of a state is physically threatened.

Editor-in-Chief of the largest Christians magazine 'The Philadelphia Trumpet' says, "Most people think the crusades are a thing of the past- over forever. But they are wrong. Preparations are being made for a final crusade, and it will be the bloodiest of all!" (Flurry, 2016).

The major part of those who keenly follow faith, idealism and moral base models are among traditional, conservative and normative societies. In contemporary era it is this arena where these major 
international theoretical perspectives confront and clash. Rest of the Asian and African nations have kept to the order of varying shades of idealist and moral ideologies.

However, all these nations are gradually drifting from its original conservative base. Rapidly Urbanized and literate population of these nations have embraced Western liberal values, secular culture and capitalist economy models whereas the majority population in rural areas have kept to their traditional and conservative base. The proponents of traditional and normative values contest the modern political theories due to its disregard for the values identified with idealistic approach and faith morals. Sharif al Mujahid a rightist scholar explains Islamic precepts in which:

"Values such as right conduct, righteousness, probity, charity, tolerance, justice, equity, compassions and benevolence are underscored. Justice and morality should govern the relations not only between individuals, but also between various groups within a nation, as well as between nations Thus interstate relations should be based on the justice and morality, rather than that of real politick, which has governed such relations since Westphalia [treaty] (1648), leading to bloody convulsions, chaos, and world wars" (Mujahid, 2001, p.134)

These precepts show the approach to human nature. The idealist approach is not based on the consequence of human action owing to his natural state. This rather warns of the consequences of an evil doing and promises reward for a good act by religious and ontological induction. This shows a clear line drawn between the adherents of 'Real Politics' and those who have grounded their precepts in idealistic religious precepts. This difference of political and social approach makes the bane of all the world conflicts. The states in the power political world try to impose their will through power and the firm believer in morals and idealism confront them with resolve in the hope of divine promise.

The issue of terrorism and chaos in Pakistani can be assumed as a confrontation between Realism and orthodoxy, one grounded in interest and the other with a faith-absolute standpoint. Realism is a political theory representing political community institutionalized as a state whereas religion has no particular institution and is characterized by infinite boundaries of social and religious traditions.

\section{Theory of Realism}

Theory of Realism has become central to international politics in the post-World Wars' international politics. The Realists resort to actions expressed in interest and realized through power. According to Jack Donnelly explains, "Political realism is a tradition of analysis that stresses the imperatives states face to pursue a power politics of the national interest (Donnely, 2005).

E.H.Carr, in the book, 'Twenty Years Crisis' (1939) wrote, "There are two facets of political science', and therefore, 'any sound political thought must be based on elements of both utopia and reality" viewed intimately, one observes, that the major part of the modern states consisting European Union is making use of the indirect realist approach influencing the world with its lead ally U.S's power based policies and are promoting their own liberal ideology in their own exclusive political sphere Carr, 1964). He argued that:

“... The tragic events of the 1930 s bore witness to the fragility of international institutions, the realities of the underlying struggle for power among states and the fallacy of a world public opinion supporting pacifism. Carr also rejected the normative underpinnings of idealism (a concern with questions of law, morality and justice) arguing instead for a 'science of international politics'..." (Jill Steans, 2001, p. 65).

Hans (1948) ublished his work 'Politics among Nations', a major work on the realist theory which has most impacted the contemporary international politics. British academic traditions stick to idealism which after evolution became liberalism; make them a natural rival of theory of Realism as they 
discard State and power and consider war as irrational act. However, the West collectively converge on common strategies and complement each other in a, politically secular and religiously Christian sphere. They share political chauvinism against communist political economic ideology and resource rich Muslim world through the ethos of faith. Faith prejudices are not in pure form like crusade as Western societies have deviated mostly to secular, liberal and realist ideologies however, undercurrent of civilizations' and religious prejudices remain permeating in their international relation conduct. The West's political theories and modern political concepts circumvent religiously barred state practices like coercive policies.

Hans. J. Morgenthau contends that, "Political realism is based upon a pluralistic conception of human nature. Real man is a composite of 'economic man', 'political man', 'moral man', 'religious man' etc. A man who was nothing but 'political man' would be a beast, for he would be completely lacking in moral restraints. A man who was nothing but 'moral man' would be a fool, for he would be completely lacking in prudence. A man who was nothing but 'religious man' would be a saint, for he would be completely lacking in worldly desires" (Hans.J. Morgenthau, 1948).

The philosophical interpretation of political realism is explained as: "Realism, also known as political realism, is a view of international politics that stresses its competitive and conflictual side. It is usually contrasted with idealism or liberalism, which tends to emphasize cooperation. Realists consider the principal actors in the international arena to be states, which are concerned with their own security, act in pursuit of their own national interests, and struggle for power. The negative side of the realists' emphasis on power and self-interest is often their scepticism regarding the relevance of ethical norms to relations among states. National politics is the realm of authority and law, whereas international politics, they sometimes claim, is a sphere without justice, characterized by active or potential conflict among states (StandforEcyclopedia, 2013)".

\section{Theory of Liberalism}

Liberal theory is based on the idea of scientific rationality, believing in individuals should be free from the arbitrary state power, persecution and superstition (Burchill, 2001). Liberals believe that war becomes unthinkable between liberal states (Dunne, 2001). Liberalism's enlightenment concept revolves around secularism, progress, reason, science, knowledge, and freedom. Liberalist theories lay emphasis on integration or close union between states. Interdependence is another feature of liberalism that helps integration between states as the dependence of one affects the decision making of other in the matters of economy and trade. Liberalism suggests the arrangement of sharing the sense of collective security which is described as Security of one is concern of all, and agrees to join in a collective response to aggression. Liberalism disagrees with Political Realism on the assumption of State as the primary actor. Liberalism puts individual and groups first and their interests and non-state actors highly important within a state (Internationalrelations, 2016).

According to Robert Keohane Liberalism has brought a paradigm shift in international relations. He says, "Since the early 1990s we can observe three developments of note: an increase in legalization; increasing legalism and moralism expressed by people leading civil society efforts to create and modify international institutions; and a decline in the coherence of some international regimes with a failure to increase the coherence of others...increasing legalism and moralism might have been expected 20 years ago by those of us who studied liberalism; but in different ways increases in legalization and recent apparent decline in the coherence of international regimes seems anomalous" (Keohane, 2012). These entire Liberal concepts to administer in Liberalism institutions and organizations play central role. The foundational theme of pluralism in which individual have special importance is nucleus of Liberalism.

There are three core assumptions as envisioned Waltz (1959):

- Essential social actors and their motivation.

- The relationship between state and civil society. 
- The circumstances under which states develop strategies and make choices in the international system

Liberalism defies allegiance of individual to the states against Realist view of allegiance to state by the individual. Andrew Moravcsid of Harvard University finds out three implications of these assumptions (Moravcsik, 1992).

- Most fundamental determinants of politics lie in society itself.

- Progress can be realized only through institutions that channel private incentives towards social goals of wealth and security.

- Possibility of evolutionary social progress under republican form of government and private economies would prevail widely.

The International Theory of Liberalism is based on the slogan, 'Democracies don't attack one another' (Katehon, 2016). Philosophically Liberals follow Locke's view about the human nature and the ability of neutrality through education this is just opposite of Realist view of human nature which they count as aggressive and evil as ascribed by Thomas Hobbes.

A summary of IR theory of Liberalism (Katehon, 2016):

- National states are not the only and in some cases not the main, actors in International Relations

- For the control of sovereign national States, a special institution may exist

- Anarchy can be overcome through democratic procedures.

- Preference of common values over national interest should be character of State behaviour.

- Not only State but the influence of a vibrant society has got a role in foreign policy and international relations.

- Democracy guarantees peace and stability.

- The State and human nature change permanently, improving and developing the growth of freedom, the strength of the democratization process, the increase in tolerance and civil responsibility.

This theory entails elements that Pakistan lacks in view of its conservative character and has emerged in recent times to form her Security Dilemma.

\section{Marxism}

Marxist approach to security is diametrical. It swaps it with global international political economy and advocates that a political economy based on the judicious distribution of wealth and resources can only grant peace and render security expenditure redundant. Marxism and social constructivism theories adopt a common approach to place security exclusive in the Realism realm. As explained by, "Wars are fought to preserve or maintain exploitative economic systems" (Hough, 2004, p. 5). Marxism describes it a class struggle to attain higher social level. These theories contend that economic and not the military or issue specific power determines the fate of the people. Marxism contends that military strategies serve the economic interest than the national interest. It takes International Relation synonym with the International Political Economy. It renders security studies superfluous and sweeps it with the Marxist theory punch line that the global security is dependent on the structural changes. Marxism concludes that individuals and people's fate are determined in the global system and not within the states and only the world socialist revolution can improve their prospects (Marx, 1848).

\section{Human Nature and Security}

The elements of security threat have been deemed, by modern political and social scientists embedded in human nature thus its response disregarding induction of morality but the reaction to reality. Hobbes, 
(1914), said, "We are needy and vulnerable. We are easily led astray in our attempts to know the world around us. Our capacity to reason is as fragile as our capacity to know; it relies upon language and is prone to error and undue influence. When we act, we may do so selfishly or impulsively or in ignorance, on the basis of faulty reasoning or bad theology or others' emotive speech'. Thomas Hobbes emphasizes on, "Natural condition of mankind...a state of violence, insecurity and constant threat". Hobbes finds a refuge for security in a power which he symbolizes with Leviathan. "The best we can hope for is peaceful life under an authoritarian-sounding sovereign," (Hobes, 2020) or Leviathan. Hobbes keeps religion subservient to Leviathan, although he believes in the presence of God, which is inherently contradictory to what he professes. Thomas Hobbes theory with regard to Security Dilemma has a relative importance, though it has been rebutted in certain regards to its application.

Rousseau criticizes this by linking it to his 'social contract'. His criticism can be summarized that a contract between parties on a single security detriment that assures peace is impaired by the lures of their inherent appetite driven by their interest that renders the contract void and dissolved; resulting in mistrust and insecurity the basic ingredients of Security Dilemma.

\section{Securitization and Security Dilemma}

According to the modern terms a finer explanation comes from Barry Buzan who argues in his work 'People States and Fear' for a wider range of security study which includes political, economic, social, environmental as well as military aspects and which is also defined in broader international terms (Buzan, 2008). For much of the cold war period the subject was dominated by the idea of national security which was largely defined in militarized terms. Buzan's extended scope leads to securitization of so many other areas of concerns that extends from military to environment. This extended security paradigm results in equally extended range of security threats; that adds to security liabilities. Thus it widens the scope of misjudged corollary leading to Security Dilemma.

Post-World Wars psyche was crucial to new international security paradigm. It resulted in creating international regimes for collective security. From the creation of League of Nations to the formulation of the concept of R2P it has mostly been West or Eurocentric thus reflective of European and US interests. This has resulted in securitization of so many social and economic areas even, which have never been directly related to the conventional security paradigm. The economic and political development gaps created vulnerability to newly emerging nation states with their inherent weakness of dependability thus becoming more prone to Security Dilemma. Pakistan is situated at an important strategic crossroads. It is exposed to threats emitting from any international confrontation. The legacy of international politics and great games involving North Western India; that is now Pakistan with Muslim identity tag is compounding the Pakistan's Security Dilemma.

'Security Dilemma' primarily used by John Hertz in international relations is further explained by (Ken Booth, 2007), “...that a country does to make it more secure will often make it less secure. This is because its actions will make other countries more likely to fear it and want to attack it before it gets too strong.", he further explains that, "Security Dilemma is integral to the International Relations as states interact and are usually not sure of the other's intentions... A dilemma by definition is worse than a problem" Security Dilemma is a condition where a state fails to appreciate its responses in the presence of an incomprehensible security threat. Interfaith and civilizations' conflicts have become the most predominant national and international security issues which range in definition between, freedom fighters, Mujahedeen, Taliban, Jihadi, fundamentalists, Islamists and finally terrorists depending on the expediency and the nature of the conflict.

\section{Constructivism}

The discontent with the earlier three paradigms brought to the fore yet another concept in 1990 known as social constructivism. According to constructivists; Realism, Marxism and Pluralism undermine the normative values and build "value free scientific models to explain the actions of national characters" 
(Hough, 2004). It brought to fore the important questions: Who is being secured? Who is doing the securing? What is it to be secure? This provokes to agitate as to only the perceived interest of a few can only result in securitization of the issues or values? And why should international actors underplay values of less privileged groups and communities?

The elements of constructive theory bring out a factor that provokes ideological tensions and perceptions ranging between resistance and terrorism. 'Malmastaiya', hospitality becomes abetting and harbouring, Jihad or resistance becomes terrorism, traditional values are portrayed as dogmas and propensity to faith becomes fundamentalism. All these factors become subject of realist orchestrations, targeting communities and groups pitched against the powerful political order. Constructivists conclude that normative values form part of the ideological thinking than wider theoretical frameworks those wouldn't pay much to achieve global peace objectives. Constructivism is the process of adapting to the surrounding and how a mind develops according to where a person lives. International relations' theories depend on the variants of development in different countries in a certain manner. Religion plays a role in social constructivism. Popular perceptions and religious constructivism impacts on state behaviour and policies.

\section{The Islamic Concept of 'Jihad'}

\section{How the Holy Quran explains it}

Pakistan's Security Dilemma is caused by conflict in Muslim and Western political perspectives. After having discussed the modern political theories it is pertinent to discuss the construct of Islamic perspectives. Islam gives an elaborate concept of Jihad or security based on projection of power, primarily for deterrence and not as a free license for waging wars at an individual level and against all non-Muslims. Jihad's wrong interpretation has a catalyst effect on Pakistan's Security Dilemma as the concept of Jihad is owned by non-state groups and even at individual level by a single suicide bomber that has created a critical state of Security Dilemma for Pakistan. It is a major concept that helps investigate conceptual base for perspectives of Jihad, political theme of terrorism and its outfall on Pakistan's Security Dilemma. The concept of power according to Quran ${ }^{2}$ is to preserve power and use it only to defend against aggression and under threat of annihilation. The first act to stop aggression is to be strong enough to deter and not attack. This Quran ayah explains it lucidly:

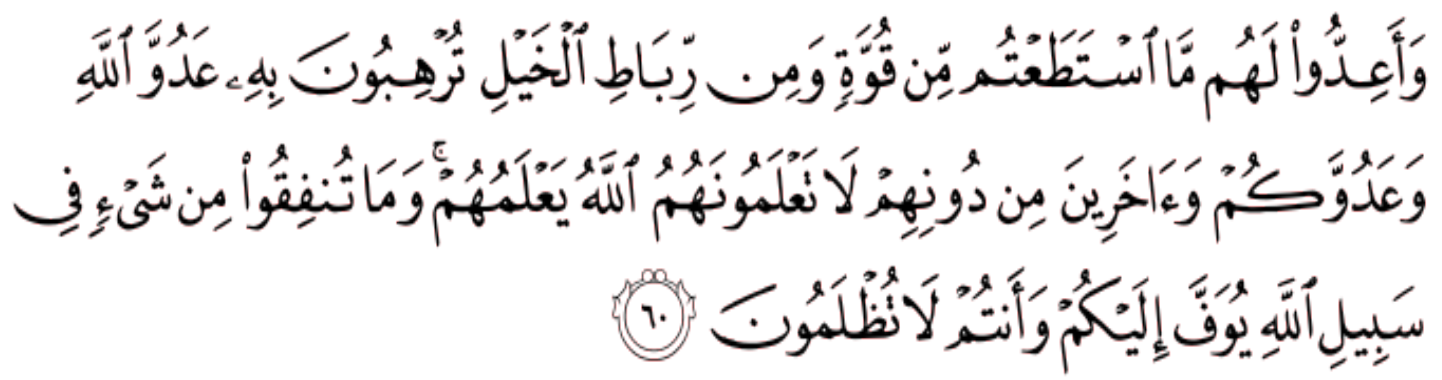

(Prepare against them whatever arms and cavalry you can muster, that you may strike terror in (the hearts of) the enemies of Allah and your own, and others besides them not known to you, but known to God. Whatever you spend in the way of God will be paid back to you in full, and no wrong will be done to you.)

Quran explains it in the very next ayah that if the enemy inclines to terms of peace be contented with their pledge and rely on Allah.

${ }^{2}$ Quran The Muslims' Holy Book 


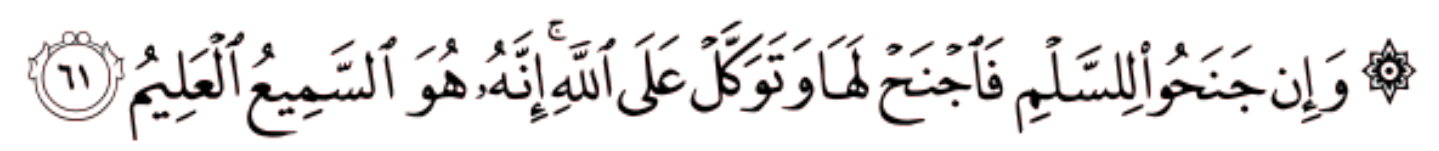

(And if they incline to peace, then incline to it [also] and rely upon Allah. Indeed, it is He who is the Hearing, the Knowing.) (Quran: 8:60-61, al Anfal).

However, Quran enjoins upon Muslims to steadily fight when under aggression and threat of annihilation when physically threatened by the enemy. This view is further augmented by the saying of Muhammad (peace be up on him) which narrates:

"Never aspire for confronting your enemies (in a war). Pray to Allah to be among those who seek living peacefully with others, but if ever you confront them (in a war) be patient and know that Heaven is as close to you as shades of the swords." (Narrated by Bukhari, Muslim Dawood)

The concept of Jihad is fundamentally based on physical threat and not under the circumstance of passive disagreements or to kill any non-Muslim. As an individual, one can support and contribute to Jihad but it overall controls rest with the Islamic Emirate or state. According to American Supreme Council of America, "...the position of the law is that only at such a time when it can be reasonably proven that; there are aggressive designs against Islam; and there are concerted efforts to eject Muslims from their legally acquired property; and, that military campaigns are being launched to eradicate them. At such a time the ruler can declare and execute the provisions of combative Jihad." (Kabbani, 2016).

The Islamic concept of Jihad or resistance motivates and glorifies death over life when it comes to fighting enemies of faith who resort to aggression and physically threatening a Muslim society. 'Muslims... coexisted amicably with non-Muslims world. The Quran does not sanctify warfare. It develops the notion of a just war of self-defence to protect decent values, but condemns killings and aggression (Armstrong, 2002, p. 26) ${ }^{3}$. It is not just about the difference of faith but is similar in nature of response like just war against a tyranny and under life threatening conditions or use of force by an enemy that endangers a society or country. It is same when we analyse the preludes of wars generally perceived. However; Islamic concept of Jihad or war securitizes religious values and not national interest or to grab strategic energy resources like the NATO countries based the war waging strategies, securitizing from environment to economy.

US used the Islamic concept of Jihad as a political theme in Muslim regions during war against communism that ended in a low intensity conflict with former USSR and her defeat. The US model of formation, making ${ }^{4}$ has diversified variables. The Muslim-atheist formation, which worked in Afghan Jihad against USSR, the terrorist and NATO and its allies' formation against War on Terrorism beginning with the event on 9 September, 2001 that helped justify the War on Terrorism. This Realist approach has been observed catalyst for Iraq, Libya, Syria, Afghanistan, Yemen, Tunis, Egypt and Algeria. This Western war mongering model will impact Pakistan's Security Dilemma as its circumstances can be simulated similar to where the Western power intended to awe it with their power and destroyed and disintegrated those countries and has almost physically annihilated those regions.

The wrong notion of Jihad and its wrong interpretation has helped non-state actors to lure Pakistani zealots for recruitment, creating individual fighters and series of suicide bombers creating a Security Dilemma for Pakistan.

\section{Meesaq-e-Madina (constitution of Madina) The Concept of Islamic Co-Existence}

\footnotetext{
${ }^{3}$ Quran 2:194, 252, 5:65, 22:40-42 (Explanatory Note '19' given at the end of the referred book.

${ }^{4}$ A strategy of crafting an enemy in US Strategic culture.
} 
Pakistan's Security Dilemma persists due to lack of grasp about the Islamic concept of co-existence or its misconstruction. The convoluted circumvention of Jihad has created turmoil in the Pakistani society and a factor of its Security Dilemma. The Islamic precepts are hedged against the social and normative ethos pretended to be faith obligations. International relations studies are dominated by European schools of thoughts. The Islamic concept of state and international relations are not given appropriate weightage and focused properly. As said by [Syed] (Khattab, 2007), a renowned Egyptian scholar on political Islam and international relations that, "Religion has re-entered politics in many ways in most parts of the world" (p.1). The major contestants being Islam, Jews and Christianity, so it is appropriate to analyse the early statecraft practices of Islam Vis a Vis modern thoughts and theories. Islamic scholars claim the efficacy of articles enshrined in the Quran and drawn from the life of the last Prophet Muhammad peace be upon him. Muslims ruled many regions and became a faith of almost a quarter of the global population due to its inherent appeal of universal and simple approach that is not cantered in a single communal interest but the whole of humanity. The foundational concept of Islamic statecraft, international relations and principle of coexistence are well documented in Islamic teachings, formulated and conducted by Prophet Muhammad S.A.W himself, under the guiding principles of the Quran. These concepts are not made in oblivion to the prevailing environment. It includes articles on plurality, diversity, social justice, rights of the minorities, freedom of religion and paganism even the rights of ownership, peaceful coexistence, collective security, and respect for life. If these Islamic concepts are grasped in its real essence contributed through intelligentsia and media, Pakistan can overcome her Security Dilemma.

The establishment of state of Medina was first Muslim Model that guides us that not the difference of faith but a threat of annihilation of a community is only cause to wage Jihad. A comparative study of Mithaq-e-Madina ${ }^{5}$ or Covenant of Medina, a document of just 730 words shows that it includes almost all the imaginable security and human rights provisions effectively executed. With the implementation of the covenant of Medina there was all peace and not a single instance of its violation was reported. Charter of Medina was drafted by Prophet Muhammad, peace be up on him himself. It was an agreement between Muslims, Jews, Christians and pagans who were brought into the fold of one Ummah or community. This brought an end to the bitter intertribal fighting between Ows and Khizrij the rival blood thirsty Arab tribes. This paradigm that established the first Islamic state of Medina successfully gives foundation for the peaceful coexistence. According to the first Islamic covenant, Islam is not a recipe for suicide bombers and terrorism but guides to peaceful coexistence with people from all faiths and creeds that even includes pagans. The salient of these concepts of coexistence and plurality are embedded in the 48 articles of Mithaq-e-Medina or the covenant of Medina:

"The Constitution introduced a number of political rights and facilities to be provided by the state to all its members, Muslims and non-Muslims alike, in return for the duties . . . the Constitution promulgated: (i) standing laws defining the rights and duties of all members, (ii) arrangements for impartial decisions on matters of right and (iii) unfailing protection of the members of the community in the enjoyment of their rights.... (i) the freedom of belief, that is, every community has the right to live according to its belief; (ii) the freedom of movement from and to Medina: 'whoever will go out is safe and whoever will stay in Medina is safe'; (iii) the assurance that if there is an external threat to non-Muslims, the Muslims would help them and vice versa; (iv) the assurance that both Muslims and non-Muslims are believers and would stand together to defend Medina against any attack; (v) the agreement that no one should go to war before consulting with the Prophet (article 36); (vi) the assurance that when consultation occurs the representatives of all parties should be present; (vii) the assurance that in cases of negotiation with foreign states, representatives of all parties should be present, and that negotiations should not be concluded unilaterally; (viii) the understanding that when a person acquires guilt they acquire it only against themselves; (ix) that a person is not liable for their ally's misdeeds; (x) that charity and goodness are clearly distinguishable from crime and injury; and (xi) that God is the guarantor of the truth and goodwill of this covenant... These are the very characteristics of the political society defined by John Locke: 'a society which fails to provide these

\footnotetext{
${ }^{5}$ The Treaty between Muslims, non-Muslim Arabs and Jews of Medina was put in writing and ratified by all parties in the year $622 \mathrm{AD}$ known as 'Misaq e Medina. For further reading, (https://www.researchgate.net/)
} 
facilities is not really a political society at all, but a continuation of the state of nature" (Sayed Khatab, 2007, p. 32).

The provision enshrined in the covenant of Median is the best recipe for a multi-religious and diversified society that is somewhat similar to Pakistan's social conditions. This model is based on pluralistic ideology focusing at social justice and protection to all members of society under a confederation to avert Security Dilemma. These universal principles can be seen reflected in piecemeal in all the political philosophies of modern times written much later than the constitution of Median that is widely believed to be the first constitution mankind ever produced. The theory of statehood in Islam is enshrined in the teachings of Quran and drawn from the life of Prophet Muhammad S.A.W. Another peculiarity is that it was formulated according to the need of the time and was promulgated and implemented in letter and spirit for the human welfare a core characteristic that breaks the restraints of national interest and sovereignty. This encompasses universal human values differentiating from realist theory that relies on the notions of interest through power. Jews and Christians with pagans even were assured and pledged safety, protection and status of equality as allies. Pagans were even assured to be protected by Muslims in case of unjust aggression and a reciprocated assurance/pledge was sought from the all parties involved including pagans. The Constitution of Medina lays universal principles that prevents making of Security Dilemma by ensuring interest of the all the stakeholders based on equality and social justice irrespective of their biological, cultural and material status. The man-made ideology strictly denies space to well appreciated concept of Islamic social and economic code. It believes in the development of mankind through natural aspirations and not through corporate and capitalist or communist paradigms in which either people are forced to produce and profit or pretend to make them equal depriving them of their property and possessions in the name of equal distribution that is unnatural and impracticable.

\section{The play-up of Modern and conservative Ethos}

Christian world characterizes with West and the US. West made a transition from religious grounding to modern political ideas of just war with an aim to penetrate Muslim dissenting cadres and even to engineer a class whose tone and tenor supported Western political thought. Strategies are being evolved where Muslim thought is injected with the secular interpretations like Cheryl Bernard, an influential scholar on US policies suggests in one of her study, "Assistance in efforts to develop education and cultural activities by secular or moderate Muslim organizations should be a priority. "Cheryl Bernard's recommendations to tame and manipulate the Muslim world are very intrusive and engineered in character as she suggests the divides between Muslim sects as an opportunity. "The United States may have an opportunity to align its policy with Shi'ite groups, who aspire to have more participation in government and greater freedoms of political and religious expression. If this alignment can be brought about, it could erect a barrier against radical Islam" (Benard, 2004).

During the crusades it was not possible for a Christian; though with secular leaning to speak against his own fellow Christians who might have misinterpreted the Bible that says, "If someone strikes you on one cheek, turn to him the other also. And if someone takes your cloak, do not withhold your tunic as well" (Luke 6:30). In a secular political environment it is possible for Muslim dissenters in the garb of a secular political class to freely speak what could not have been easily expressed, had the West and Islam been contesting on purely religious grounds. Muslim world overwhelmingly characterized orthodoxy and religiosity and its concept of war didn't change much from the original concept of Jihad since the advent of Islam.

\footnotetext{
${ }^{6}$ The source retrieval on the page from this reference is downloaded: Rabasa, Angel, Cheryl Bernard, Peter Chalk, C. Christine Fair, Theodore W. Karasik, Rollie Lal, Ian O. Lesser and David E. Thaler. US Strategy in the Muslim World after 9/11. Santa Monica, CA: RAND Corporation, 2004.

http://www.rand.org/pubs/research_briefs/RB151.html...

${ }^{7}$ which she refers to Sunni presumably
} 
In the restructured political environment the Western ideals were expressed through the medium of the state. At people's level in Muslim world they found state lacking to express the will of the people that caused the emergence of non-state actors' role among the wider Muslim world.

In the Muslim world, people believe in the concept of Ummah that transcended boundaries of state and entails a universal and International vision that contrasts the local sensibility and form of modern nation State. This religious spirit de corps (Ummah) motivates an international Muslim brotherhood. These results in homogenous religious pulse where action of one is deemed conflated on the whole of Muslim strata all over the world. In actuality this is what also causes threats as the Muslim majority countries' reaction to any atrocity or offensive action is reacted throughout the Muslim world. Since the consequence of Muslim political reaction at the people level is not filtered through the mostly secular Muslim modern states this is taken on by the non-state actors.

The role of non-state actors undermined the higher institution of sovereign states. It can be analysed that it erodes the state's authority and their control leads to confrontation and result in creating Security Dilemma of most of the Muslim states with Pakistan at the top. The Muslim states' secular inclination also resulted in the making of Islamic factions. These groups emerged as a reaction to contest the modern political forces to block modern political and social changes. The modern political dynamism failed to overcome religious influence on the Muslim societies with their modern ideology and could not bring any change in state and religion's relations and Islamic beliefs of the people of Muslim countries but to create a minority of secular liberal class that further complicated the already worsening situations, The clash between these conflicting phenomena resulted in a Security Dilemma.

In the case of Christianity as observed by Johnson (1997) in his book, 'The holy war idea in the Western and Islamic traditions' has noted that, "Perhaps the fundamental point is that the idea of holy war never enjoyed a secure place in the Western world doctrine on war and statecraft for a variety of reasons, of which three are most important. First, the idea of a holy war in Western culture had not one, but several often conflicting substantive forms rationales for such warfare, particularly conceptions of justifying authorization and conduct have accordingly been discontinued and sometime conflicting. Second, the relation of religion to the state has been ambivalent from the beginning, so that ideal of holy war is not at the core of Christian self-understanding, but is rather an idea associated with particular historical period and form of religion and political relationship. And, third, the major normative traditional war and statecraft in the West is not that of holy war, but that of the just war, a broad culture consensus shared by temporal as well as religious influences." (Johnson, 1997).

The argument of just war has broadened the arena of war conception in the West. A Realism perspective extends all forms of justifications for a war beyond the religious or moral paradigms. This conception of realization of national interest objectives through power frustrates the religious sentiments and has broadened the range of securitization that includes trade to environment and human rights.

Territorial integrity and security of state enterprise and trade routes used to be a few among security concerns before the advent of broadened securitization perspectives. The extended range of securitization gives equally extended range of coercive tools to the West for arms twisting of nations and regime changes where its interest is deemed at stake.

Pakistan is situated at the crossroads of strategic geographic hub, thus bears the brunt of confrontations and conflicts among all the militarily powerful nations. It remains dependent on the West due to the inherent weak industrial structure that leaves the only option of going by the West leaning international political tide than carve out its own ingenious international relation response. The Western military overtures in pursuit of their interest and lack of befitting response at the state level have pushed religious cadres as non-state actors to fill the gap. This makes the security paradigm more complex as non-state actors fight simultaneously internally and globally. They believe external powers in direct confrontation and their own state as supporters of secular world who perpetrate conspiracies against their faith. This is what has become a double security trap factoring the most in contemporary security 
threats faced by Pakistan and Muslim world in general. Pakistan is precariously finding ways to extricate from this state of Security Dilemma.

The man who led this 21 st century Jihad against the Western and Judeo-Christian military and political preponderance was Sheikh Osama Bin Awad Bin Muhammad Bin Laden famously called Osama Bin Laden (OBL). Osama Bin Laden was not a typical terrorist caste. A former CIA officer who served for a long time writes, "The threat America faces from Bin Laden is not the episodic terrorist campaign typical of those perpetrated by traditional terrorists groups. It is rather a worldwide, religiously inspired and professionally guided Islamist insurgency against "Christian crusaders and Jews," which is being waged by groups Bin Laden has controlled, directed, and inspired". Michael quotes the words of a prominent Islamist lawyer Muntasir al Zayyat making his view point more elaborate, "They [the Americans] deal with Usama Bin Laden, [Gam'at al-Islamiyah spiritual leader] Shykh Umar Abd-alRahman, and [Egyptian Islamic Jihad chief] Ayman al Zawahiri, as if they were carbon copies of [the] international terrorist Carlos, and that reflects their inability to understand the facts of the matter. Carlos was a terrorist whose activities stopped when he was arrested.

The fundamentalist movement's leaders are ideas, a heritage, a stature, and principles that do not disappear when they disappear" explaining what the American missed Michael writes, "While we all have seen and viscerally felt the damage Bin Laden has unleashed on the United Sates, most do not have a coherent understanding of what motivates the threat his movement poses. Or, if some have heard what he has said-such phrases as, "If we cut off the head of America, the kingdom in the Arab world will cease to exist". They have dismissed it as hyperbolic rhetoric meant to win notoriety and thereby have missed the substantial kernel of truth at the statement's core" (Schueuer, 2006, p. xxiii). Another author Philip Towle from Cambridge department of politics writes, "Recognizing that terrorists are not insane is the first step in understanding them." (Towle, 2006, p. 130).

The emergence of OBL cast a direct bearing on Pakistan's present Security Dilemma. Osama bin Laden funded and fought with a religious perspective and motivation that converged tactically with national interest of USA to fight a common enemy. Taliban replaced Mujahedeen as an umbrella for Jihad continuum. As the later events were anti-US as Taliban deemed US as Afghanistan's occupant and now their enemy. Pakistan faced a dilemma as the depth it sought in Afghanistan was not possible without stabilizing it and after the US anti-Taliban stance things went rough and difficult and was rather shaping up in a perpetual turmoil. India remained the major problem with a dispute over Jammu and Kashmir still pending. The question arose whether India remained the only major threat or Pakistan has earned many more security threats due to its policy faults.

Pakistan's Security Dilemma can better be analysed beyond its dispute with India on the issue of state of Jammu and Kashmir. Dispute with India is a major factor that has indirectly yielded even bigger security threats rather than solving single one. Pakistan is part of the Muslim world and at the international level a model has been established where Muslim states have contributed naively to the Western and US causes and lost their own interest and objectives. The Muslim world has been played up by the West and US, according to the respective regional issues manipulating through regional divides. The Western nations' nexus with US on top supported and played up these warring factions to create leverage with the calibrated political risk that has mostly culminated in favour of Western and US interest so far.

\section{Conclusion}

Pakistan's meek security and political situation can be exploited through Realpolitik. Pakistan if not conducive to the interest of US and other NATO nations can face numerous threats emitting from political philosophy of powerful countries. Pakistan is not fully sovereign in the wake of emerging political theories that explain sovereignty not a right but responsibility. The new emerging theory, R2P passed as UN resolution, answers the questions raised by constructivists that, "Who is being secured? Who is doing the securing? What is it to be secured? This shifts the responsibility of securing people in a sovereign state to international community when any such government if found by them failing to do 
so. This creates a threat of creation of a chaotic situation to bring a target state on anvil by the international real politic players as has been perceived in case of Afghanistan, Iraq and Libya are deemed to be projected in case of Iranian nuclear plans and potential theme projection about Pakistan's nuclear weapons that it might slip into the hands of Taliban thus qualifies to be rescued and controlled by the international regimes favourable to the interest of NATO nations. This concept of collective security and global security has a gap. In the case of NATO, collective security has implied in the sense of regional security. NATO's aims and objectives are not global but primarily to provide security mechanism to protect European regions as explained by NATO on its website, "Article 5 is at the basis of a fundamental principle of the North Atlantic Treaty Organization. It provides that if a NATO Ally is victim of an armed attack, each and every other member of the Alliance will consider this act of violence as an armed attack against all members and will take the actions it deems necessary to assist the Ally attacked." (North Atlantic Treaty Organization, 2005). These factors pose a Security Dilemma to Pakistan. Pakistan is under disproportionate foreign influence in the matters of its policy making. Pakistan's policy lacks the hierarchal scrutiny and input in its policy making. There are signs of growing foreign ingress in Pakistan's policy matters aimed at influencing society, official working, media, and independent fraternization and recruiting Pakistani citizens, aimed at working for their own national interest with lesser regards for the national interest of Pakistan. Pakistan has been portrayed as a state 'descending into chaos' and akin to the proportions of a failed state, an observation that is hard to be separated from fact and projection, purposeful to power politics that can paint such a situation causes belli and casus foederis to push turmoil ridden Pakistan in Security Dilemma. The lack of hierarchical, intellectual, scholarly and statesmanship input, political articulations, dynamism in Pakistan foreign policy as compared to the European and North Americans peculiar strategic cultures; make it all the more difficult to solve the security dilemma.

\section{References}

Anatol Lieven. (2011). A Washington Post web page. Retrieved from Opinion: http://www.washingtonpost.com/opinions/five-myths-about pakistan/2011/05/24/AGkPs4HH_print.html

Armstrong, K. (2002). Islam: A Short History. London, UK: Phonix.

Benard, C. (2004). U.S. Strategy in the Muslim world After 9/11. US: Rand: Project Air Force.

Burchill, S. (2001). Theoires of International Relations . New York: Palgrave.

Buzan, B. (2008). People States and Fear: An Agenda for International Security Studies in the Postcold War Era. Colchester, UK: ECPR Press.

Carr, E. H. (1964). Twenty Years' Crisis, 1919-1939. HarperCollins.

Donnely, J. (2005). Theories of International Relations (Third Edition). New York: Palgrave.

Dunne, T. (2001). The Golbalization of the World Politics. Bath, Avon, UK: Oxford University Press.

Eck, D. L. (2016, November 8). The Pluralism Project. Retrieved from Harvard University web site: http://pluralism.org/what-is-pluralism/

Flurry, G. (2016). The Trumpet. Retrieved from The Trumpet web site : https://www.thetrumpet.com/article/507.24.35.0/middle-east/israel/the-last-crusade

Hans. J. Morgenthau, K. T. (1948). Politics Among Nations. Lahore: Vanguard Books.

Hobbes, T. (1914). Leviathan. London: J.M. Dent \& Sons.

Hobes, T. (2020). Internet Encyclopedia of Philosophy. Retrieved January 2, 2020, from https://www.iep.utm.edu/hobmoral/

Hough, P. (2004). Understanding global security. London: Routledge.

Internationalrelations. (2016, December 15). Liberalism . Retrieved from International Relations.org : $\mathrm{http}: / /$ internationalrelations.org/liberalismpluralism/

Jill, S. (2001). An Introduction to International Theories . Essex, England: Pearson Education Lmited.

Johnson, J. T. (1997). The Holy war idea in Western and Islamic traditions. Pensalovania : Pensalovania state press.

Kabbani, S. H. (2016). Understanding Islam . Retrieved from The Islamic Srpeme Council of America: http://www.islamicsupremecouncil.org/understanding-islam/legal-rulings/21-jihadclassical-islamic-perspective.html?start $=9$ 
DOI: https://doi.org/10.47405/mjssh.v5i9.471

Katehon. (2016). Principles of liberalism in International Relation . Retrieved from A Katehon web site: http://katehon.com/article/principles-liberalism-international-relations

Ken Booth, N. W. (2007). The Security Dilemma. Palgrave.

Keohane, R. (2012). Twenty Years of Institutional Liberalism. International Relations Vol.26 , 125138.

Mansfield, E. D. (1994). Pwer, trade, and war. Princeton, N. J.: Princeton University Press.

Marx. (1848). Manifesto of the Communst Party. Retrieved from Marxists.org: https://www.marxists.org/archive/marx/works/1848/communist-manifesto/

Moravcsik, A. (1992). Liberalism and International Relations Theory. Chicago: University of Chicago.

Mujahid, S. a. (2001, p.134). logy of Pakistan. Rawalpindi: Services Book Club.

Sayed Khatab, G. D. (2007). Democracy in Islam. Oxon: Routledge.

Schueuer, M. (2006). Through our Enemies's Eyes . Washington D.C.: Potomic Book, Inc. .

StandforEcyclopedia. (2013, April 2). Political Realism in International Relations. Retrieved from A standfor university web site: https://plato.stanford.edu/entries/realism-intl-relations/

Stoessinger. (2010). Why nations go to war. Boston: Wadsworth Cengage Learning.

Towle, R. J. (2006). Temptations of Power: Politics after 9/11. New York U.S.A.: Palgrave .

Waltz, K. N. (1959). Man, the State, and War: A Theoratical Analysis. New York: Columbia University Press. 